lasting mark on the entire field. Throughout his nearly forty years at Penn, he was a good friend and a wise counselor.

Born in New Rochelle, New York, on 8 November 1942, Elliott was educated at Wesleyan University (BA, 1964) and Princeton University (PhD, 1968) where he worked with Clarence Brown. Elliott then surprised his colleagues in the field by earning a JD degree at the University of Pennsylvania Law School in 1974. The law degree was simply more evidence of his broad range of interests and profound learning. At Penn he served several terms as chair of the department of Slavic languages, transforming it from an undergraduate training ground for students going elsewhere for an advanced degree to a robust research department, maintaining a high reputation for teaching undergraduates while creating a strong doctoral program. From this base he organized and led the scholars at Penn specializing in the Soviet Union and eastern Europe to establish a Center for Soviet and East European Studies under Title VI and then, as director, obtained a $\$ 500,000$ grant from the Andrew W. Mellon Foundation to support the center's research activities. At Penn he also served as associate dean for undergraduate studies and associate dean for planning and development. In all his administrative positions, Elliott exhibited a tolerance, patience, and moral authority than one expects and does not often observe in these capacities.

When he took over the editorship of Slavic Review, he introduced several important innovations. Sensitive to the special needs of scholars in the social sciences for a faster turnaround, he sped up the review process; he also added a section on film reviews, encouraged discussion pieces, and generally enlivened its pages with a variety of formats. His personal contribution took the form of short, elegantly written, and learned essays. No longer than two pages, they were much more than a summary of the main articles. Rather, inspired by the contents of the journal, these pieces reflected his own wide-ranging reading and thinking about issues at the cutting edge of scholarship. They are still worth rereading today.

Elliott was a pioneer in the study of Boris Pasternak's prose and poetry. In collaboration with E. B. and E. V. Pasternak, the poet's son and daughter-in-law, he launched a massive project in 1975 to publish the manuscripts of the novel Doctor Zhivago. At the same time, he began preparing the correspondence between Pasternak and $\mathrm{Ol}^{\prime}$ ga Freidenberg, which he compiled, edited, helped to translate, and introduced in a lengthy commentary. It was published first in English in 1982, with Russian and French editions following in close succession; publication in several other languages came later. Elliott had plans to write a major monograph, "Boris Pasternak: The Poetics of Prose," based upon a complete edition of the correspondence. Unfortunately, he did not live to see this project completed, although parts of it appeared in scholarly journals.

Elliott's interest in the law evolved into a research project on how the social institutions of central planning and the contractual regulation of relationships between juridical persons have interacted historically and continued to do so in the late Soviet period. He taught the substance of this project when he was Ida Beam Distinguished Visiting Professor of Law at the University of Iowa Law School in 1983.

Elliott was widely respected by his colleagues and cherished by his friends; he inspired both loyalty and affection in his students. Elliott is succeeded by his daughter, Ellen, an honors student at Penn, his sister, Marion, and brothers Donald, Dwight, and Garrett.

ALFRED RIEBER
Central European University, Budapest
April 2007

\title{
Heinrich A. Stammler, 1912-2006
}

Heinrich A. Stammler was born on 15 December 1912, in Jena, Germany. He passed away on 29 November 2006, in Lawrence, Kansas, surrounded by his family: his wife, Ursula Hofmann Stammler; his daughter, Andrea Lewis, and her husband, Patrick; his son, 
Christopher Stammler, and his wife, Kathren; and three grandchildren, Annika and Aidan Lewis and Elijah Stammler.

Having received a classical education at gymnasia in Hannover and Greifswald, Heinrich studied Slavic languages and literatures at the universities of Greifswald (while still at gymnasium), Munich, and Prague. While in Prague he met the famous Eurasianist thinker, Petr Savitskii, who urged the young student to dedicate himself wholly to Russian. During the academic year 1934-1935, Heinrich was attached to the German Embassy in Moscow. In 1937 he completed his PhD in Slavic on Russian folk poetry ("Die russische geistliche Volksdichtung") at the University of Munich. The same year he moved to Bulgaria where he taught modern foreign languages at the Svishtov Business College until 1940. During these three happy years he perfected his Bulgarian language skills and became friends with a number of Bulgarian poets like Teodor Traianov. Between 1940 and 1942, when he was drafted into the army, he worked briefly in the German Embassy in Sofia. In 1945 he became a prisoner of war under the Americans.

After the war Heinrich returned to Munich where he initially taught Russian and American literature at the Munich Volkshochschule and American literature and civilization at the University of Munich. He also taught English and Russian to future interpreters at the Dolmetscher Institut. In 1952 Heinrich received a grant for German scholars from the U.S. State Department that enabled him to visit American universities and colleges. In 1953 he accepted a position in German and Russian at Northwestern University in Evanston, Illinois. In 1960, he and his wife moved to the University of Kansas, and in 1962 he became the first chair of the new Department of Slavic Languages and Literatures. A Slavic scholar with a deep knowledge of continental philosophy and Eastern Orthodox thought, Heinrich made the department famous for its offerings in Russian and Slavic intellectual history, a tradition that continues even today.

Heinrich was the epitome of the philologist and humanist: he studied, interpreted, and passed on to later generations the broad picture of the achievements of centuries of human culture. Anyone who conversed for more than a few minutes with him rapidly appreciated his encyclopedic knowledge of languages (he knew at least eight), linguistics, literature, philosophy, and history.

As a Slavicist, Heinrich published articles in all three branches of the Slavic language family - South, West, and East Slavic. In addition, he translated Bulgarian and Russian poetry into exquisite German. Most recently, in 2000, his outstanding translations of Evgenii Baratynskii were republished in a second edition. He may have enjoyed one of the longer publication records in memory, for it extended over sixty years from 1939 to 2006. In May of last year he reissued a small but rich booklet of haiku that he had composed.

With his usual modesty Heinrich once said that he felt he lacked the langer Atem (the stamina) to write monographs and books. This assessment had little to do with reality. His book-length translation of works by the Russian philosopher and critic, Vasilii Rozanov, his monograph on Rozanov, his lengthy work on the poet Nikolai Kliuev, and his articles on Dmitrii Merezhkovskii and Vladimir Solov'ev broke new ground. Heinrich addressed issues in literature and culture that might not have been very popular at the moment, but that later attracted a great deal of attention and stimulated further work. Such was his work with the older generation of Russian symbolists, Russian philosophy, and the Bulgarian symbolist, Traianov.

Heinrich represented an essential link in the chain of generations through which the Russian cultural renaissance extending from 1890 to 1930 has been kept alive. He studied in Munich with the well-known philosopher and cultural historian, Fedor Stepun, who himself played a part in that flowering of Russian philosophical and religious culture. Stammler brought those intellectual riches with him when he moved to the United States in the early 1950s and to Kansas in the early 1960s. That there are currently three faculty in the Slavic department and one in the philosophy department who write and teach on philosophical and intellectual-historical themes, and particularly the era of the Russian renaissance, is a sign that the tradition he brought to the United States and founded at the University of Kansas is alive and well.

On the lighter side, Heinrich collected and loved to read and reread the works of P. G. Wodehouse. In a way, he lived that era: he was always the impeccably dressed gentle- 
man, coming to even the most informal gathering in a jacket and tie. He had a superior memory, and even to his last days he could quote long passages of German and Russian poetry and loved to sing songs and tell jokes. In his later years he would reread Augustine in Latin just to keep that wonderful memory in shape.

In a very real sense, Heinrich represented what the "globalized" world could be- not the domination of one language and culture over all others but the capacity to function in many cultures and languages, supported with intimate knowledge and deep respect for their peoples and traditions.

Edith W. Clowes

University of Kansas April 2007

\section{Victor Terras, 1921-2006}

Victor Terras, author of literally hundreds of books, articles, and reviews and adviser to countless students, passed away on 17 December 2006. We all mourn his loss.

Born in Estonia, Victor was educated in Tallinn and Kraków, receiving his master's degree in 1942 in Indo-European and Slavic linguistics, and teaching his first courses in Greek and Latin at the University of Tartu. Together with these ancient languages, his native Estonian, Russian, Polish, German, French, and of course English, Victor also knew Sanskrit and, at least later in life, Portuguese. A quick check of the table of contents of this very issue will prove his knowledge of yet another language and subject matter; several months ago his wife, Rita, sent Slavic Review Victor's final review, which he dictated to her while already very ill with Parkinson's disease. The book, on the Ukrainian Orthodox Church, was written in Italian. Victor's career was as long as it was wide-ranging. He came to the United States in 1952, was naturalized in 1956, and soon resumed his graduate work, receiving a $\mathrm{PhD}$ in Slavic languages and literatures from the University of Chicago in 1963. He taught at the University of Illinois and the University of Wisconsin and retired from his final position as the Henry Ledyard Goddard University Professor of Slavic Languages and Comparative Literature at Brown University in 1988.

Retirement did not end Victor's publishing career. Adding to his earlier accomplishments, including The Young Dostoevsky: A Critical Study (1969) and his absolutely indispensable Handbook of Russian Literature (1984), while "slowing down" he published a Twayne series book on The Idiot (1990), then the thorough and sometimes provocative History of Russian Literature (1991), and the often brilliant Poetry of the Silver Age (1998), before returning to his early interest with Reading Dostoevsky (1998). At the same time, he published on just about all of the major figures in nineteenth- and twentieth-century Russian literature, including Aleksandr Pushkin, Nikolai Gogol', Ivan Turgenev, Lev Tolstoi, Anton Chekhov, Isaak Babel' (with my favorite article on line and color in Red Cavalry), Vladimir Maiakovskii, and his real love, Osip Mandel'shtam. Indeed, Victor was at work on a major book about Mandel'shtam when he died, and, according to a Mandel'shtam expert here at Wisconsin, Andrew Reynolds, Victor's "article on time in Mandel'shtam is still one of the best things written on the subject."

Perhaps Wisconsin attracts scholars who move in Victor's footsteps. David Danaher, a colleague who first knew Victor, not here, but at Brown, wrote the following recollection. I reproduce it in full, since it reflects both Victor's fame and his typical humility:

$I$ taught at Brown for a year as a lecturer and it was determined that $I$ would need to share an office with the recently retired Professor Terras. He was using a cane to walk at the time, and it was a common sight to see him making his way up to his office and then, at the end of the day, down again, tightly gripping the banister and patiently navigating the stairs, without ever complaining and always refusing offers of help. 